\title{
Вивчення особливостей бактеріальної транслокації при комплексному післяопераціӥному лікуванні хворих на гостру декомпенсовану спайкову тонкокишкову непрохідність
}

\begin{abstract}
Мета роботи: вивчити рівень та динаміку бактеріальної транслокації у хворих на гостру спайкову кишкову непрохідність, оперованих у стадії декомпенсації.

Матеріали і методи. Обстежено та прооперовано 69 хворих на гостру спайкову тонкокишкову непрохідність у стадії декомпенсації. 3 метою вивчення рівня бактеріальної транслокації виконували бакпосів виділень із дренажів та назогастроінтестинального (НГІ) зонда в динаміці лікування в післяопераційному періоді.

Результати досліджень та їх обговорення. У роботі вивчено кількісний та якісний склад мікрофлори тонкої кишки та перитонеального ексудату під впливом комплексного лікування із застосуванням лаважу кишечника 0,9 \% розчином натрію хлориду в поєднанні з оксигенотерапією та ентеральним харчуванням розчином “Пептамен” у хворих на гостру спайкову тонкокишкову непрохідність у стадії декомпенсації. Виявлено меншу колонізацію кишечника та контамінацію черевної порожнини кишковою паличкою, умовно-патогенними мікроорганізмами, та більш швидке відновлення біоценозу тонкої кишки при застосуванні розробленого комплексу заходів дало можливість знизити рівень післяопераційних ускладнень та летальності.
\end{abstract}

Ключові слова: гостра спайкова кишкова непрохідність; бактеріальна транслокація; назогастроінтестинальний зонд.

Постановка проблеми і аналіз останніх досліджень та публікацій. За останні роки частота гострої спайкової кишкової непрохідності (ГСКН) зросла у 2 рази та знаходиться на першому місці серед причин механічної кишкової непрохідності серед усіх її видів непухлинного генезу [1]. За даними різних авторів, її частота знаходиться в межах від 50 до 93,3 \%, що зумовлено щорічним зростанням кількості хворих, оперованих на органах черевної порожнини [1, 2]. Висока летальність при цій патології зумовлена розвитком ендотоксикозу та поліорганної недостатності [3].

Одним із загрозливих і прогностично несприятливих ускладнень гострої спайкової непрхідності тонкої кишки $є$ розвиток синдрому ентеральної недостатності (CЕН). СЕН виникає внаслідок моторно-евакуаторних порушень кишечника та призводить до змін бар'єрної, секреторної, резорбтивної функції тонкої кишки, а також пристінкового та порожнинного травлення $[4,5]$.

Розвиток кишкової непрохідності супроводжується транслокацією бактерій, які колонізують просвіт кишечника, порушенням їх співвідношення на користь умовно-патогенних бактерій. Характер бактеріальної транслокації (БТ) визначається станом слизової оболонки кишечника, імунної системи та складом колонізуючої мікрофлори $[6,7]$. За рахунок контамінації різноманітними бактеріальними популяціями з дистальних відділів кишечника здійснюється надмірна коло- нізація тонкого кишечника. Кишковий стаз і парез призводять до швидкого збільшення концентрації внутрішньокишкової мікрофлори та резорбції токсинів, особливо в тонкому кишечнику [8]. На розвиток БТ також впливає внутрішньочеревна гіпертензія, якою завжди супроводжується ГСКН, що $є$ пусковим механізмом порушення роботи різних органів і систем [9].

В Україні та інших країнах для декомпресії шлунково-кишкового тракту при ГСКН активно застосовують інтубацію тонкої кишки, попри сучасні тенденції без застосування цієї методики у США та багатьох країнах Європи. Інтубаційний зонд також використовують для ентерального харчування та ранньої корекції гемостазу [10].

Тому оптимізація існуючих та розробка нових комплексних патогенетично обгрунтованих підходів післяопераційного лікування хворих на ГСКН $є$ актуальним, а дослідження мікробіоценозу кишечника та ексудату черевної порожнини у таких пацієнтів $є$ вкрай важливим для оцінки стану хворого та прогнозу перебігу післяопераційного періоду.

Мета роботи: вивчити рівень та динаміку бактеріальної транслокації у хворих на гостру спайкову кишкову непрохідність, оперованих у стадії декомпенсації.

Матеріали і методи. У роботі проаналізовано результати клінічного обстеження та хірургічно- 
го лікування 69 хворих на гостру спайкову декомпенсовану тонкокишкову непрохідність. 3 них чоловіків було 27 (34,2 \%), жінок - 52 (65,8 \%), переважали особи працездатного віку від 31 до 60 років, що склало 72,5 \%. Дослідження виконували на базі КНП “Тернопільська університетська лікарня” ТОР з 2015 до 2020 р.

Обстежувані пацієнти були розділені на 2 групи. Основну групу $(\mathrm{n}=42)$ склали пацієнти, яким після усунення причини кишкової непрохідності інтраопераційно виконували назогастроінтестинальну інтубацію (НГІІ). Пацієнтам цієї групи в післяопераційному періоді НГІ зонд використовували для проведення лаважу, оксигенотерапії (патент України на корисну модель № 81097) та ентерального харчування. Лаваж кишечника проводили 0,9 \% розчином $\mathrm{NaCl}$, ентеральне харчування розпочинали з появою перистальтики (2-3 доба післяопераційного періоду) за допомогою розчину “Пептамен”. Контрольну групу (n=27) склали пацієнти, яким після усунення причини кишкової непрохідності інтраопераційно виконували НГІІ. Пацієнтам цієї групи в післяопераційному періоді інтубаційний (НГІ) зонд використовували лише для декомпресії та пасивного відтоку кишкового вмісту.

3 метою вивчення рівня бактеріальної транслокації виконували бакпосів виділень із дренажів та НГІ зонда в динаміці лікування через 1, 3 та 5 діб післяопераційного періоду. Мікробіологічні дослідження виконували за загальноприйнятими методами [11].

Результати досліджень та їх обговорення. При аналізі мікробіологічних досліджень встановлено, що па першу добу після операції кількість умовно-патогенних ентеробактерій (E. coli, Proteus vulgaris, Klebsiella spp., Enterobacter cloaceae) у виділеннях із дренажів в основній групі хворих складала $(5,33 \pm 0,12) \mathrm{KУO/г.} \mathrm{У} \mathrm{контрольній} \mathrm{групі} \mathrm{даний}$ показник становив $(6,09 \pm 0,15) \mathrm{KУO} / г$.
На третю добу після операції спостерігалось незначне зниження рівня умовно-патогенних ентеробактерій у виділеннях із дренажів в основній та контрольній групах хворих і становило $(4,00 \pm 0,18) \mathrm{KУO} / г$ та $(4,94 \pm 0,18)$ КУО/г відповідно (табл. 1).

На п’яту добу після операції спостерігалось значне зниження бактеріальної контамінації виділень з черевної порожнини в основній групі хворих, яким у післяопераційному періоді проводили комплекс лікувальних заходів за запропонованим способом. У контрольній групі хворих, які були проліковані традиційно, на п'яту післяопераційну добу кількість умовно-патогенних ентеробактерій знизилась незначно порівняно з третьою добою $((4,33 \pm 0,12)$ і $(4,94 \pm 0,18)$ КУО/г відповідно).

При мікробіологічному аналізі виділень із НГІ зодна кількість облігатних анаеробних мікроорганізмів (Bifidumbaccilus, Lactobaccilus) та кількість E. coli в досліджуваних групах була майже на одному рівні станом на першу добу після операції $(4,00 \pm 0,14) \mathrm{i}(3,80 \pm 0,14) \mathrm{KУO} / г$ - облігатні анаеробні мікроорганізми, $(7,12 \pm 0,21)$ i $(7,10 \pm 0,14) \mathrm{KУO} / \Gamma$ - E. coli відповідно. Ці показники значно відрізнялись від норми $((7,6 \pm 0,20) \mathrm{KУO} / г$ - нормальний рівень біфідум- та лактобактерій, $(1,50 \pm 0,10) \mathrm{KУО/г}$ - нормальний рівень E. coli в тонкому кишечнику), що може свідчити про глибокий дисбіоз тонкого кишечника, спричинений даною патологією.

Отже, суттєве зниження колонізації умовнопатогенними ентеробактеріями виділень з дренажів спостерігали на п'яту добу післяопераційного періоду в основній (використання запропонованого комплексу лікувальних заходів) у цій групі пацієнтів.

Хворі контрольної групи не зазнали значної позитивної динаміки в плані зниження бактеріальної контамінації виділень з дренажів у досліджуваний післяопераційний період.

Таблиця 1. Показники бактеріального спектра виділень із назогастроінтестинального зонда та випоту перитонеального ексудату із дренажів в оперованих хворих на третю добу післяопераційного періоду

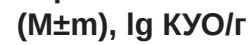

\begin{tabular}{||c|c|c|c||}
\hline \multirow{2}{*}{ Групи хворих } & \multicolumn{2}{|c|}{$\begin{array}{c}\text { Бактеріальний спектр виділень } \\
\text { з зонда }\end{array}$} & $\begin{array}{c}\text { Бактеріальний спектр виділень } \\
\text { дренажів }\end{array}$ \\
\cline { 1 - 4 } & $\begin{array}{c}\text { кількісний склад облігатних } \\
\text { анаеробних мікроорганізмів }\end{array}$ & $\begin{array}{c}\text { кількісний склад } \\
\text { Е. coli }\end{array}$ & $\begin{array}{c}\text { кількісний склад умовно- } \\
\text { патогенних ентеробактерій }\end{array}$ \\
\hline Контрольна (n=27) & $2,73 \pm 0,13$ & $6,82 \pm 0,17$ & $4,94 \pm 0,18$ \\
\hline Основна (n=42) & $4,13 \pm 0,14$ & $5,80 \pm 0,14$ & $4,00 \pm 0,18$ \\
\hline
\end{tabular}


При посівах вмісту із НГІ зонда на третій день після операції (табл. 1) спостерігали зниження більш ніж на 25,0 \% кількості облігатних анаеробних мікроорганізмів $((2,73 \pm 0,13) \mathrm{KУО} / г)$ у контрольній групі хворих на противагу кількісному рівню E. coli, який залишався в межах $(6,82 \pm 0,17)$ КУО/г. Ці дані можуть свідчити про посилення дисбіотичних змін у тонкому кишечнику хворих контрольної групи.

Кількісний склад облігатних анаеробних мікроорганізмів, виділених із зонда хворих основної групи, не зазнав суттєвих змін на третю добу після операції і незначно зріс, порівняно з першим днем після операції, та становив $(4,13 \pm 0,14) \mathrm{KУО/г.}$ Проте кількісний склад E. coli, виділеної із зонда хворих основної групи, знизився майже на 20 \% i становив $(5,80 \pm 0,14) \mathrm{KУО/г,} \mathrm{що} \mathrm{свідчить} \mathrm{про} \mathrm{пози-}$ тивну динаміку відновлення мікробіоценозу тонкого кишечника хворих основної групи (табл. 1).

Кількість облігатних анаеробних мікроорганізмів у просвіті тонкого кишечника на п’яту добу післяопераційного періоду зросла як в контроль- ній, так і в основній групах хворих, що свідчить про позитивну динаміку відновлення облігатної мікрофлори тонкого кишечника. Проте кількісний рівень кишкової палички у виділеннях із НГІ зонда у контрольній групі хворих перевищував вдвічі $((5,82 \pm 0,13) \mathrm{KУО/г)} \mathrm{аналогічний} \mathrm{показник} \mathrm{основ-}$ ної групи хворих $((2,63 \pm 0,12) \mathrm{KУO} / г)$. Цей факт може вказувати на більшу колонізацію кишковою паличкою просвіту тонкого кишечника хворих, лікованих традиційним способом.

Кількісний рівень E. coli у виділеннях із НГІ зонда в перший день після операції в основній та контрольній групах хворих був майже на одному рівні (рис. 1).

Зниження контамінації кишковою паличкою дослідного матеріалу на третю добу після операції також було встановлено в обох групах хворих. Проте на п’яту добу в основній групі спостерігали значно меншу колонізацію кишковою паличкою вмісту із НГІ зонда, ніж у контрольній групі (рис. 1). Це свідчить про швидше відновлення мікробіоценозу тонкого кишечника в основній групі хворих.

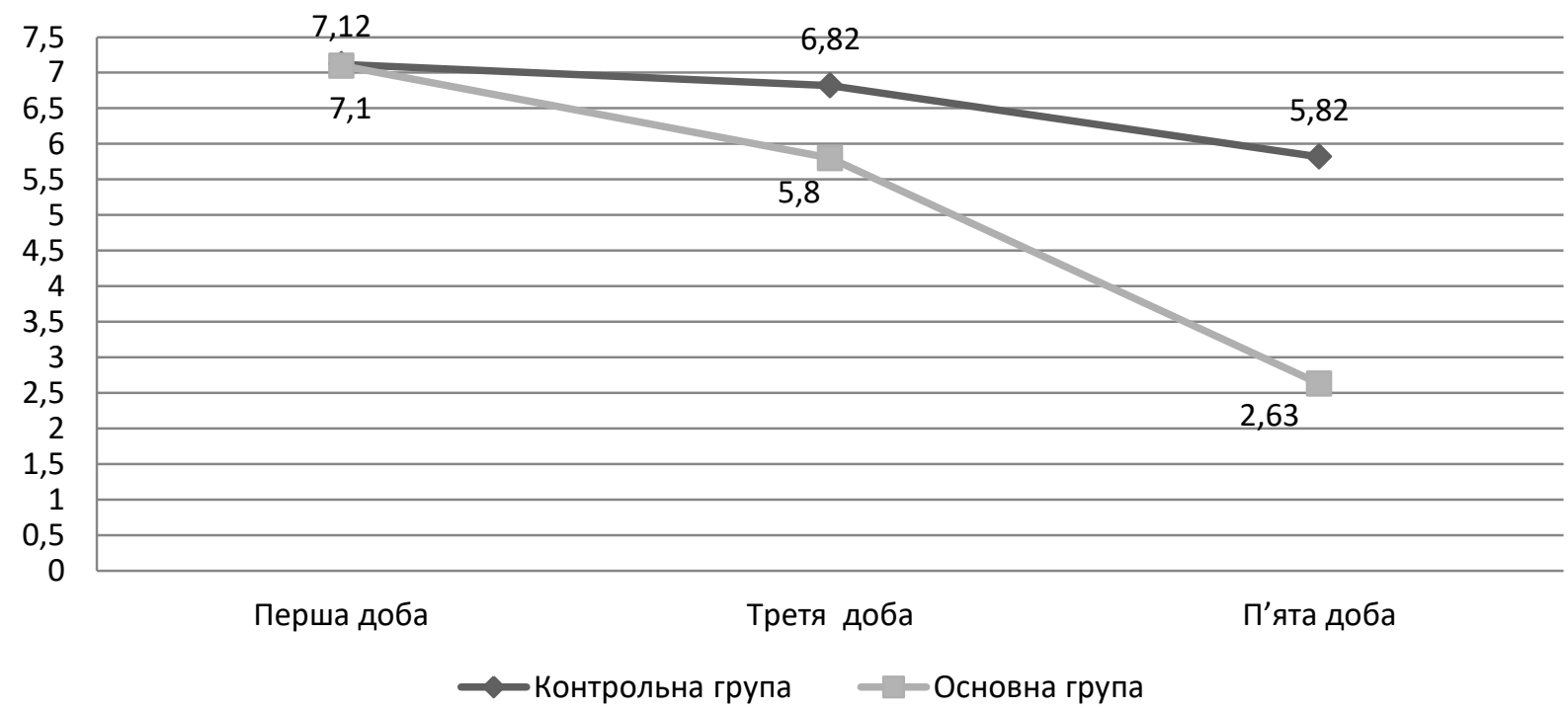

Рис. 1. Зміна кількісного складу E. coli у виділеннях із НГІ зонда.

До 5 доби післяопераційного лікування, кількісний склад облігатних анаеробних мікроорганізмів, виділених із зонда контрольної групи хворих, зазнав істотніших змін, ніж основної групи.

Так, на третю добу після операції в контрольній групі хворих було виявлено зниження кількості біфідо- і лактобактерій у виділеннях із НГІ зонда майже на третину (3,80 КУО/г - на першу до- бу після операції, 2,73 КУО/г - на третю добу). В основній групі хворих цей показник був стабільним (4,0 КУО/г - на першу добу після операції, 4,13 КУО/г - на третю добу). На п’яту добу після операції показники кількісного рівня облігатних анаеробних мікроорганізмів зросли в обох групах (5,47 КУО/г - в контрольній групі хворих, 6,09 КУО/г - в основній групі). 


\section{З ДОСВІДУ РОБОТИ}

Висновки. 1. У хворих на гостру спайкову кишкову непрохідність спостерігається дисбіоз кишкового вмісту.

2. При розвитку синдрому кишкової недостатності спостерігається бактеріальна транслокація в черевну порожнину.

\section{СПИСОК ЛІТЕРАТУРИ}

1. Бойко В. В. Післяопераційне лікування хворих на гостру спайкову кишкову непрохідність / В. В. Бойко, В. Я. Пак, В. 3. Микитин // Харківська хірургічна школа. - 2018. - № 1 (88). - C. 74-78.

2. Декомпресія тонкої кишки в хірургічному лікуванні хворих із синдромом ентеральної недостатності / В. П. Польовий, С. І. Райляну, О. О. Карлійчук [та ін.] // Харківська хірургічна школа. - 2018. - № 1 (88). - С. 139-143.

3. Diagnosis of small intestinal bacterial overgrowth in the clinical practice / M. Gabrielli, G. D’angelo, T. Dirienzo [et al.] // European Review for Medical and Pharmacological Sciences. 2013. - Vol. 17 (Suppl. 2). - P. 30-35.

4. Современное состояние вопроса острой спаечной кишечной непроходимости / В. В. Бойко, И. А. Тарабан, Д. А. Евтушенко [и др.] // Харківська хірургічна школа. - 2014. - № 1. C. 87-90.

5. New paradigms in the treatment of small bowel obstruction / M. T. Dayton, D. T. Dempsey, G. M. Larson, A. R. Posner // Curr. Probl. Surg. - 2012. - Vol. 49, No. 11. - P. 642-717.

6. Diagnosis of small intestinal bacterial overgrowth in the clinical practice / M. Gabrielli, G. D’angelo, T. Dirienzo // European Review for Medical and Pharmacological Sciences. 2013. - Vol. 17 (Suppl. 2). - P. 30-35.

\section{REFERENCES}

1. Boiko, V.V., Pak, V.Ya., \& Mykytyn, V.Z. (2018). Pisliaoperatsiine likuvannia khvorykh na hostru spaikovu kyshkovu neprokhidnist [Postoperative treatment of patients with acute adhesive intestinal obstruction]. Kharkivska khirurhichna shkola Kharkiv Surgical School, 1 (88), 74-78 [in Ukrainian].

2. Polovyi, V.P., Railianu, S.I., Karliichuk, O.O., Palianytsia, A.S., Filipets, O.I., \& Stupnytskyi, V.V. (2018). Dekompresiia tonkoi kyshky v khirurhichnomu likuvanni khvorykh iz syndromom enteralnoi nedostatnosti [Decompression of the small intestine in the surgical treatment of patients with syndrome of enteral insufficiency]. Kharkivska khirurhichna shkola - Kharkiv Surgical School, 1 (88), 139-143 [in Ukrainian].

3. Gabrielli, M., Dangelo, G., Dirienzo, T., Scarpellini, E., \& Ojetti, V. (2013). Diagnosis of small intestinal bacterial overgrowth in the clinical practice. European Review for Medical and Pharmacological Sciences, 17 (Suppl. 2), 30-35.

4. Boyko, V.V., Taraban, I.A., \& Evtushenko, D.A. (2014). Sovremennoe sostoyanie voprosa ostroy spaechnoy kishechnoy neprohodimosti [The current state of the issue of acute adhesive intestinal obstruction] Kharkivska khirurhichna shkola - Kharkiv Surgical School, 1, 87-90 [in Russian].

5. Dayton, M.T., Dempsey, D.T., Larson, G.M., \& Posner, A.R. (2012). New paradigms in the treatment of small bowel obstruction. Curr. Probl. Surg, 49 (11), 642-717.

6. Gabrielli, M., Dangelo, G., Dirienzo, T., Scarpellini, E., \& Ojet-
3. Застовування запропонованого способу лікування забезпечило більш швидке відновлення якісного та кількісного складу мікрофлори тонкої кишки і зменшити частоту післяопераційних ускладнень та рівень летальності.

7. Chang Hwan Choi. The role of small intestinal overgrowth in functional gastrointestinal disorders / Chang Hwan Choi, Sae Kyung Chang // Journal of neurogastroenterology and Motility. 2016. - Vol. 22. - P. 3-5.

8. Гриценко Є. М. Ультразвукова діагностика синдрому ентеральної недостатності при гострій хірургічній патології органів черевної порожнини у дітей / Є. М. Гриценко, В. С. Барійчук, М. Гриценко / Матеріали 3-го Конгресу Української асоціації спеціалістів ультразвукової діагностики, м. Одеса, 9-11 червня. 2008 р. Одеса. - С. 30-31.

9. Бодяка В. Ю. Вплив внутрішньочеревної гіпертензії на особливості бактеріальної транслокації після моделювання та хірургічного лікування гострої кишкової непрохідності / В. Ю. Бодяка // Український журнал хірургії. - 2012. - № 4 (19). - C. 96-100.

10. Лігоненко О. В. Рання біологічна ентеральна терапія у комплексному лікуванні хворих на гостру кишкову непрохідність / О. В. Лігоненко, І. І. Дігтяр, О. О. Лігоненко // Шпитальна хірургія. - 2011. - № 3. - С. 26-29.

11. Методики клинических лабораторных исследований. Т. 3. Клиническая микробиология : справочное пособие / под ред. В. В. Меньшикова. - Москва : Лабора, 2009. - 880 с.

ti, V. (2013). Diagnosis of small intestinal bacterial overgrowth in the clinical practice. European Review for Medical and Pharmacological Sciences. 17 (Suppl. 2), 30-35.

7. Chang Hwan Choi, \& Sae Kyung Chang (2016). The role of small intestinal overgrowth in functional gastrointestinal disorders. Journal of Neurogastroenterology and Motility, 22, 3-5. 8. Hrytsenko, Ye.M., Bariichuk, V.S., \& Hrytsenko, M.I. (2008). Ultrazvukova diahnostyka syndromu enteralnoi nedostatnosti pry hostrii khirurhichnii patolohii orhaniv cherevnoi porozhnyny u ditei [Ultrasound diagnosis of enteric insufficiency syndrome in acute surgical pathology of the abdominal cavity in children]. $M a$ terialy 3-ho Konhresu Ukrainskoi asotsiatsii spetsialistiv ultrazvukovoi diahnostyky - Proceedings of the 3rd Congress of the Ukrainian Association of Ultrasound Diagnostics, Odesa [in Ukrainian]. 9. Bodiaka, V.Yu. (2012). Vplyv vnutrishnocherevnoi hipertenzii na osoblyvosti bakterialnoi translokatsii pislia modeliuvannia ta khirurhichnoho likuvannia hostroi kyshkovoi neprokhidnosti [Influence of intra-abdominal hypertension on features of bacterial translocation after modeling and surgical treatment of acute intestinal obstruction]. Ukrainskyi zhurnal khirurhii - Ukrainian Journal of Surgery, 4 (19), 96-100 [in Ukrainian].

10. Lihonenko, O.V., Dihtiar, I.I., \& Lihonenko, O.O. (2011). Rannia biolohichna enteralna terapiia u kompleksnomu likuvanni khvorykh na hostru kyshkovu neprokhidnist [Early biological enteral therapy in the complex treatment of patients with acute in- 
testinal obstruction]. Shpytalna khirurhiia - Hospital Surgery, 3, 26-29 [in Ukrainian].

11. Menshikov, V.V. (2009). Metodiki klinicheskih laboratornyh issledovaniy. T. 3. Klinicheskaya mikrobiologiya: spravochnoe posobie [Clinical laboratory research methods. T. 3. Clinical microbiology: a reference manual]. Moscow: Labora [in Russian].

Отримано 16.02.2021

Електронна адреса для листування: andrew_burak@tdmu.edu.ua

\author{
A. D. BEDENUYK, A. YE. BURAK
}

I. Horbachevsky Ternopil National Medical University

\title{
STUDY OF THE FEATURES OF BACTERIAL TRANSLOCATION IN THE COMPLEX POSTOPERATIVE TREATMENT OF PATIENTS WITH ACUTE DECOMPENSATED ADHESIVE SMALL INTESTINAL OBSTRUCTION
}

\begin{abstract}
The aim of the work: to study the level and dynamics of bacterial translocation in patients with acute adhesive intestinal obstruction operated in the stage of decompensation.

Materials and Methods. 69 patients with acute adhesive small bowel obstruction in the decompensation stage were examined and operated on. In order to study the level of bacterial translocation, bacterial swab tests of secretions from drainages and nasogastrointestinal (NGI) probe were performed in the dynamics of treatment in the postoperative period.

Results and Discussion. The quantitative and qualitative composition of the small intestinal microflora and peritoneal exudate under the influence of complex treatment with intestinal lavage with $0.9 \%$ sodium chloride solution in combination with oxygen therapy and enteral nutrition with "Peptamen" solution in patients with acute adhesive intestinal obstruction in the stage decompensation. Less colonization of the intestine and contamination of the abdominal cavity with Escherichia coli, opportunistic pathogens and faster recovery of the biocenosis of the small intestine using the developed set of measures allowed reducing the level of postoperative complications and mortality.
\end{abstract}

Key words: acute adhesive intestinal obstruction; bacterial translocation; NGI probe.

\author{
А. Д. БЕДЕНЮК, А. Е. БУРАК
}

Тернопольский национальный медицинский университет имени И. Я. Горбачевского

\section{ИЗУЧЕНИЕ ОСОБЕННОСТЕЙ БАКТЕРИАЛЬНОЙ ТРАНС.ЛОКАЦИИ ПРИ КОМПЛЕКСНОМ ПОС.ЛЕОПЕРАЦИОННОМ ЛЕЧЕНИИ БОЛЬНЫХ ОСТРОЙ ДЕКОМПЕНСИРОВАННОЙ СПАЕЧНОЙ ТОНКОКИШЕЧНОЙ НЕПРОХОДИМОСТЬЮ}

Цель работы: изучить уровень и динамику бактериальной транслокации у больных острой спаечной кишечной непроходимостью, оперированных в стадии декомпенсации.

Материалы и методы. Обследовано и прооперировано 69 больных острой спаечной тонкокишечной непроходимостью в стадии декомпенсации. С целью изучения уровня бактериальной транслокации выполняли бакпосев выделений из дренажей и назогастроинтестинального (НГИ) зонда в динамике лечения в послеоперационном периоде.

Результаты исследований и их обсуждение. В работе изучено количественный и качественный состав микрофлоры тонкой кишки и перитонеального экссудата под влиянием комплексного лечения с применением лаважа кишечника 0,9 \% раствором натрия хлорида в сочетании с оксигенотерапией и энтеральным питанием раствором «Пептамен» у больных острой спаечной тонкокишечной непроходимостью в стадии декомпенсации. Выявлено меньшую колонизацию кишечника и контаминацию брюшной полости кишечной палочкой, условно-патогенными микроорганизмами, и более быстрое восстановление биоценоза тонкой кишки при применении разработанного комплекса мер позволило снизить уровень послеоперационных осложнений и летальности.

Ключевые слова: острая спаечная кишечная непроходимость; бактериальная транслокация; назогастроинтестинальный зонд. 